\title{
Comparison of Four Patterns of Management of Coastal Tourism Destinations in Bali-Indonesia
}

\author{
Made Antara \\ Lecturer at Tourism Doctoral Program and Researcher at Tourism Research Consortium, \\ Universitas Udayana
}

Corresponding author: antara_unud@yahoo.com

\section{ARTICLE INFO}

Received

20 September 2015

Accepted

29 January 2016

Available online

07 March 2016

\begin{abstract}
Utilization of coastal in Bali tourism destination by investor is to build of hotel, bar and restaurant, and to develop beach tourism attractions, and so location of tourists expose to the sun known with term 3S is Sea, Sand, Sun. There are four patterns of management of coastal tourism destinatyion in Bali, nemaly, (1) Pattern of management by village tradition; (2) Pattern of management by village foundation; (3) Pattern of management by government authority/agency; and (4) Natural development (without pattern of management). The pattern of management by village tradition was applied in Kuta beach and Jimbaran beach in Badung regency. The pattern of management by village foundation was applied to manage of Sanur beach in Denpasar city. The pattern of management by government authority/agency was used to manage of Nusa Dua beach and surrounding in Badung regency. Meanwhile, natural development (without pattern of management) was used in many beaches in Bali, like Nusa Lembongan island beach in Klungkung regency. Two management patterns management by village tradition and management by village foundation initiatives by local community and its developing, local community livelihood in all long of beach very depending on tourism. While, management by authority agency initiatives are mainly applied by the central government in Jakarta. Coastal tourism managed through the three kinds of management approaches are generally good, particularly on environmental security, tourists safety, maintaining clean environment which are made possible through mobilization of task forces. On the other hand, coastal areas without planned tourism management, generally suffers from several problems. Hence the development of sustainable coastal tourism should be managed by one of institution which may be that of a local community or a governmental authority/agency.
\end{abstract}

Keywords: pattern of management, sustainable, coastal, tourism.

\section{Introduction}

The development of tourism has been oscillating for the last decades, associated with various factors, such as financial crisis (1997/1998-2000), 9/11 tragedy, Gulf War, issues on SARS (Severe Acute Respiratory Syndrome), and issues on terrorism. At present, the global monetary crisis is also of great influence on tourism, because it affects the disposable income of the Americans, Europeans, and spread to Asian countries. This once again strengthens the position that amidst its potential as an engine of economic growth, tourism is also susceptible to external disturbances. As stated by the World Travel and Tourism Council (Theobald 1994, in Ariani (2004), tourism has been the biggest 
industry in the world, seen from economic indicators such as total output, value added, investment, labour, and tax contribution for the government in many countries. Tourism is a significant industry in British Columbia; it generates more than $4 \%$ of the real GDP and about $7 \%$ of employment. By comparison, it is only slightly smaller than BC's construction industry.

For Indonesia, the importance of tourim had been strongly stated in the Outlines of State Policy (1998), it is stated that,

"Pembangunan kepariwisataan diarahkan pada pengembangan pariwisata sebagai sektor andalan dan unggulan dalam artian luas yang mampu menjadi salah satu penghasil devisa, mendorong pertumbuhan ekonomi, meningkatkan pendapatan daerah,memberdayakan perekonomian masyarakat, memperluas lapangan kerja dan kesempatan berusaha, serta meningkatkan pengenalan dan pemasaran produk nasional dalam rangka meningkatkan kesejahteraan rakyat dengan tetap memelihara kepribadian bangsa, nilai-nilai agama serta kelestarian fungsi dan mutu lingkungan hidup".

It is clearly dictated that tourism is developed to become a main sector in the national economic development, while at the same time maintains the national identity and environmental sustainability.

Tourism is wide spanning, in the sense that it consists of various service industries related to the facilitation of travelers, such as restaurant, accommodation, transportation, and souvenir (Yoeti, 1996). As such, labor absorbed by this sector is significantly high, with a close correlation with the development of tourism service industries, tourism infrastructures, and tourism attractions. The number of labor used in tourism sector at the end is associated with the number of tourist arrival and expenditure.

A number of analyses have stated that tourism development triggers labor mobility (Vorlauter, 1996). (Radetzki-Stenner, 1989) also states that the development of tourism has become the main pull factor in the immigration of labor. Interestingly, the level of education of those involved in tourism is relatively above of those on other economic sectors.
The number of tourist visiting Indonesia in 2008 reaches $6.4 \mathrm{M}$, with a significant increase compare to that of 2007 (5.5 M). The arrival of 2007 itself is an increase of $13.02 \%$ compared to that of 2006 (Depbudpar, 2007). Seen from nationality, ASEAN countries, especially Singapore and Malaysia, are the main sources of tourist visiting Indonesia.

From economic perspective, positive impacts of tourism, in Bali can be seen from several indicators, namely (1) as a source of foreign exchange for the country, (2) a potential market for goods and services produced by the local community, (3) to increase the community income whose activities are directly or indirectly related to services of tourism, (4) to increase the job opportunity, either in direct-linkage sectors such as hotel, restaurant, and travel agent, or at indirect linkage sectors such as handicraft industry, supply of agricultural produce, cultural attraction, retail business, and the other service activities, (5) as a source of region's indirect taxes, and (6) to stimulate the artists' creativity, such as those in small-scale industry or in traditional performing arts (Antara and Pitana, 2009).

Thus, tourism, wherever it is, including in Bali has arisen positive impact for regional and national economy, in other side, it also gives negative impact such as decrease of potential farming area for supporting the tourism infrastructure development, increase the crime, traffic jam, urbanization, migration, arising of shop, shopping centre, mall which violet the rules of environment, environment degradation and pollution. The last negative impact mentioned above called negative externality $=$ external cost $=$ external diseconomy such tourism activity that arise environment damage, water pollution (river sea and well ) and earth, so that it causes social lost guaranteed by society around the tourist objects.

From micro point of view, to decrease negative externality caused by tourism can be conducted throughout some policies, such giving incentive in form of subside or taxes discounted (hotel and restaurant) to the tourism supporting agents (such as restaurant, travel agent, scuba diving, etc) which give such protection or maintain the sustainability for environment. As an example : hotels or 
travel agents which recycle the waste either solid or liquid waste (sewage), so that it does not arise pollution to the land or water around it. In return, government apply disincentive in term of increase of taxes (taxes for hotel and restaurant or fine for any tourism supporting agencies) which pollute the environment, whether air, earth or other pollution which cause the disadvantage for community.

From macro point of view, so tourism has great rate in increasing national and regional income. If it is formulated in a form of macroeconomic model, so regional and national income accounted from expense side as follows

$$
\mathrm{Y}=\mathrm{C}+\mathrm{I}+\mathrm{G}+\mathrm{E}-\mathrm{M}
$$

Where is, $\mathrm{Y}=$ national or regional income; $\mathrm{C}=$ society consumption expenses; $\mathrm{I}$ = private investment expense; $\mathrm{G}=$ government expense; $\mathrm{E}=$ export; $\mathrm{M}=$ import. If tourism is progressively developed means that there will be an increase of tourist visit, it also means that there is increase of tourist expense in tourism object. So, there will be automatically an increase of income for society, government, private businessmen and export of tourism services. Furthermore, this income is repurchased or expended, so it causes an increase for $\mathrm{C}, \mathrm{I}, \mathrm{G}$ and $\mathrm{E}$ and will finally increase the total income for regional/national income (Y).

However, as it has been mentioned above, tourism also affects an externality particularly negative externality which both directly and indirectly causes nature resource degradation, water pollution, earth, etc. So, they will effect to disadvantages which must be guaranteed by society (external social cost). If this external social cost is internalized into real cost will factually decrease the regional or national income. Therefore, macro-economic model must previously corrected by entering negative external component into the model.

\section{$\mathrm{Y}=\mathrm{C}+\mathrm{I}+\mathrm{G}+\mathrm{E}-\mathrm{M}+$ NEGATIVE EXTERNALITY}

Due to externality produced by tourism is negative externality. So, the achieved economic growth is required to be decreased or in other word, it is required to do economic valuation from the resource used on regional or national economic activities.

\section{The Role of Tourism in the Economy}

\section{Case: Indonesia}

If assumed tourism represented by Trade, Hotel and Restaurant sector has a significant contribution to the economy of Indonesia, as can be seen from its share to GDP (Gross Domestic Product). From trade, hotel and restaurant alone, tourism contributes $16.15 \%$ in 2000 , decrease to be $13.69 \%$ in 2010 , and increase to be $14.60 \%$ in 2014 in 2007 at current price (Table 1). The share of tourism on GDP is seconded only by manufacturing. If tourism supporting industries are included (i.e. transportation, communication, finance, and other services), tourism would be the biggest contributor in the formation of Indonesian GDP.

The other economic indicator of tourism is the foreign exchange earned, which is important for any country in doing international transaction. Through money changer or banking system, foreign currencies are exchanged to local currencies at destination. In foreign exchange earning, tourism contributes the fifth biggest in 20102010. The position of tourism increase, and in 2013-2014 is the forth (Table 2). The fluctuation of this position is closely associated with the fluctuation of tourist arrival to the country. Even though fluctuating, it is clear that the role of tourism is significant in the economic development of Indonesia. Even more if the indirect economic impacts are calculated, such as poverty alleviation and job creation. 
Table 1.

Share of Economic Sectors on Gross Domestic Bruto of Indonesia According Current Price (in Percent)

\begin{tabular}{|l|r|r|r|r|r|r|r|}
\hline \multirow{2}{*}{ Sectors } & \multicolumn{7}{|c|}{ Share to GDP at Current Market Price (\%) } \\
\cline { 2 - 8 } & 2000 & \multicolumn{1}{|c|}{2005} & \multicolumn{1}{|c|}{2010} & 2011 & \multicolumn{1}{c}{2012} & 2013 & $\left.2014^{*}\right)$ \\
\hline $\begin{array}{l}\text { 1. Agriculture, Forestry, } \\
\text { Animal Husbandry and } \\
\text { Fishery }\end{array}$ & 15.60 & 13.13 & 15.29 & 14.71 & 14.50 & 14.42 & 14.33 \\
\hline 2. Quarrying & 12.07 & 11.14 & 11.16 & 11.82 & 11.81 & 11.29 & 10.49 \\
\hline 3. Manufacturing & 27.75 & 27.41 & 24.80 & 24.34 & 23.96 & 23.69 & 23.71 \\
\hline $\begin{array}{l}\text { 4. Electricity, Gas and } \\
\text { Water Supply }\end{array}$ & 0.60 & 0.96 & 0.76 & 0.75 & 0.76 & 0.77 & 0.80 \\
\hline 5. Construction & 5.51 & 7.03 & 10.25 & 10.16 & 10.26 & 9.98 & 10.05 \\
\hline $\begin{array}{l}\text { 6. Trade, Hotel and } \\
\text { Restaurant }\end{array}$ & 16.15 & 15.56 & 13.69 & 13.80 & 13.96 & 14.32 & 14.60 \\
\hline $\begin{array}{l}\text { 7. Trantsportation and } \\
\text { Communication }\end{array}$ & 4.68 & 6.51 & 6.56 & 6.62 & 6.67 & 6.99 & 7.39 \\
\hline $\begin{array}{l}\text { 8. Financial, Insurance, } \\
\text { and Enterprise Services }\end{array}$ & 8.31 & 8.31 & 7.24 & 7.21 & 7.27 & 7.52 & 7.65 \\
\hline 9. Other Services & 9.34 & 9.96 & 10.24 & 10.58 & 10.81 & 11.01 & 10.98 \\
\hline \multicolumn{1}{|c|}{ GDP } & 100.00 & 100.00 & 100.00 & 100.00 & 100.00 & 100.00 & 100.00 \\
\hline
\end{tabular}

Source: Website of Central Bureau of Statistics (Downloaded April 19, 2016)

Note: $*)=$ temporary data

Table 2

Foreign Exchange of Tourism in Comparison to the Other Export Commodities, 2010-2024 (million USD)

\begin{tabular}{|c|c|c|c|c|c|c|}
\hline No. & Commodity & 2010 & 2011 & 2012 & 2013 & 2014 \\
\hline 1 & 0il \& gas & $28.039,60(1)$ & $41,477,10(1)$ & $36,977,00(1)$ & $32.633 .20(1)$ & $30.318,80(1)$ \\
\hline 2 & Coal & $18.499,30(2)$ & $27221,80(2)$ & $26.166 .30(2)$ & $24,501,40$ (2) & $20.819,30(2)$ \\
\hline 3 & Palm oil & $13.468,97(3)$ & $17.261,30(3)$ & $18.845,00(3)$ & $15.839,10(3)$ & $17.464,90(3)$ \\
\hline 4 & Processer & $9.314,97(4)$ & $14258,20(4)$ & $10.394,50(4)$ & $9.316,60(5)$ & $7.021,70(6)$ \\
\hline$\underline{5}$ & Tourism & $7.003,45(5)$ & $8.554,39(5)$ & $9.120,85(5)$ & $10.054,15(4)$ & $11.166,13(4)$ \\
\hline 6 & Finished doth & $6.598,11(6)$ & $7.801,50(6)$ & $7.304,70(6)$ & $7.501,00(6)$ & $7.450,90(5)$ \\
\hline 7 & Electrictools & $6.337,50(7)$ & $7.364,30(7)$ & $6.481,90(7)$ & $6.418,60(7)$ & $6.259,10(8)$ \\
\hline 8 & Textiles & $4.721,77(8)$ & $5.563,30(8)$ & $5.278,10(8)$ & $\begin{array}{r}5.293,60(9) \\
\end{array}$ & $5.379,70(9)$ \\
\hline 9 & $\begin{array}{l}\text { Paper and paper } \\
\text { products }\end{array}$ & $4.241,79(9)$ & $4.214,40$ (11) & $3.972 .00(10)$ & $3.802 .20(10)$ & $3.780,00(12)$ \\
\hline 10 & processed foods & $3.620,86(10)$ & $4.802,10(9)$ & $5.135,60(9)$ & $5.434,80(8)$ & $6.486,80(7)$ \\
\hline 11 & Chemical material & $3.381,85(11)$ & $4.630,00(10)$ & $3.636,30(11)$ & $3.501,60(12)$ & $3.853,70(11)$ \\
\hline 12 & Processed wood & $2.870,49(12)$ & $3.288,90(12)$ & $3.337,70(12)$ & $3.514,50(11)$ & $3.914,10(10)$ \\
\hline
\end{tabular}

Source: Website of Tourism Ministry of Republikc of Indonesia (Downloaded April 19, 2016)

\section{Case: Bali}

A better outlook can be drawn from the case of Bali, the tourism capital of Indonesia. Because of the intensity of tourism development in the island, the economy of this island-province is that of tourism-dominance, quite different from the other provinces in Indonesia. Tourism has become the leading sector in the economy, pushing other economic activities. The dominance of tourism has led the network of the economy spreads from local, national and international. These results in the significant contribution of the related sectors, such as hotel, restaurant, trade, transportation, finance, and other services, to the formation of the regional GDP and foreign exchange earning.

In the period of 2010-2014, the sector called 'trade, hotel and restaurant' contributes averagely $29.10 \%$ to the GDP. Its share to the GDP fluctuates, related to the fluctuation of tourist arrival. In 2010, tourism contributes $27.82 \%$ to the formation of Bali's GDP; in 2011 it increased to $28.25 \%$, its contribution to GDP increase down to $31,35 \%$ in 2014.

However, if the economic sectors are grouped into three main sectors (primary, secondary, and tertiary sectors), and tertiary sector assumed represent tourism sector, the economic structure of Bali is steady, that tertiary sectors dominates the economic structure. In 2010, tertiary sectors contributed $65.28 \%$ to the island's GDP, and in 2011 it reaches $67.16 \%$. Secondary sectors' contribution also decrease from $16.34 \%$ in 2010 to $16.10 \%$ in 2011 . On the other hand, the role of primary sectors decreases from $18.38 \%$ in 2010 to $17.48 \%$ in 2011 (Table 3 ). This is in line with the general patterns that the increase of the per capita income tends to hand in hand with the decrease of the role of primary sectors. The economic structure tends to shift from primary to secondary and tertiary.

The role of tourism in the economy is not only indicated by its contribution in the formation of GDP, but also from tourist's expenditure on goods and services during their stay in Bali. Tourist's expenditure brings about direct and indirect impacts. The direct impact is the value of money spent to directly buy goods and services in the destination, while the indirect impacts involves the expenditure for goods and services that do not directly influence economic sectors producing such goods and services. 
Table 3

The Formation of Bali's GDP by Sector, at Current Prices, 2010-2014

\begin{tabular}{|c|c|c|c|c|c|c|}
\hline \multirow{2}{*}{$\mathrm{N}_{0}$} & \multirow{2}{*}{ Sector } & \multicolumn{5}{|c|}{ Share to GDP at Current Market Price $(\%)$} \\
\hline & & 2010 & 2011 & 2012 & 2012 & 2014 \\
\hline I & Primary Sector & 18.38 & 17.48 & 17.01 & 16.53 & 15.89 \\
\hline 1 & Agriculture & 17.17 & 16.23 & 15.7 & 15.22 & 14.64 \\
\hline 2 & Quanrying & 1.21 & 1.25 & 1.31 & 1.31 & 1.25 \\
\hline II & Secondary Sector & 16.34 & 16.1 & 17.08 & 16.64 & 15.72 \\
\hline 3 & Manufacturing & 7.00 & 6.69 & 6.53 & 6.44 & 6.38 \\
\hline 4 & Electricity \& Water Supply & 0.46 & 0.43 & 0.41 & 0.33 & 0.32 \\
\hline 5 & Construction & 8.88 & 8.98 & 10.14 & 9.87 & 9.02 \\
\hline III & Tertiary Sector & 65.28 & 67.16 & 68.18 & 66.34 & 63.22 \\
\hline 6 & Trade, Hotel and Restaurant & 27.82 & 28.25 & 28.23 & 29.84 & 31.35 \\
\hline 7 & Transpoortation and Communication & 13.67 & 13.88 & 13.82 & 14.28 & 14.22 \\
\hline 8 & $\begin{array}{l}\text { Banling and Other Financial } \\
\text { Intermediaries }\end{array}$ & 9.91 & 9.65 & 9.86 & 9.74 & 9.48 \\
\hline 9 & Services & 13.88 & 14.64 & 13.66 & 13.4 & 13.23 \\
\hline & Total & 100.00 & 100.00 & 100.00 & 100.00 & 100.00 \\
\hline
\end{tabular}

Source: Website of Central Bureau of Statistics of Bali Province (processed) (Downloaded April 23, 2016).

The direct impact of tourism on the local economy can be seen from the value of tourists' expenditure (international and domestic). Meanwhile, total tourist expenditure per year in Bali is determined by the total tourist arrivals per year, the average length of stay of tourists and the average tourist expenditure per person per day. Assuming the average length of stay of tourists and the average tourist expenditure per person per day remains unchanged, the total expenditure of tourists every year in Bali will increase with the increase in tourist arrivals to Bali. Moreover, if the average length of stay and average tourist expenditure per person per day increased, then it is definitely spending tourists in Bali increased larger. As shown in Table 4, tourist arrivals to Bali in 2004 only amounted to $1,457,565$ people, in 2008 increased to $2,085,084$ people, in 2010 increased to 2,576,142 and in 2014 increased to $3,766,638$ people. So it seems clear that the increase in tourist arrivals to Bali every year will increase tourist spending and increase in tourist visits will be income of tourism stakeholders, will eventually be able to improve the economic activities Bali.
Table 4

Foreign Tourist Arrivals to Bali (People)

\begin{tabular}{|l|c|c|c|c|c|c|c|}
\hline \multicolumn{1}{|c|}{ Month } & 2004 & 2008 & 2010 & 2011 & 2012 & 2013 & 2014 \\
\hline January & 104057 & 147799 & 179273 & 209093 & 253286 & 232935 & 279257 \\
\hline February & 84368 & 161776 & 191926 & 207195 & 225993 & 241868 & 275795 \\
\hline March & 99826 & 160708 & 192579 & 207907 & 230957 & 252210 & 276573 \\
\hline April & 111022 & 154911 & 184907 & 224704 & 225488 & 242369 & 280096 \\
\hline May & 117191 & 167463 & 203388 & 209058 & 220700 & 247972 & 286033 \\
\hline June & 131685 & 178404 & 228045 & 245652 & 244080 & 275667 & 330396 \\
\hline July & 148086 & 190854 & 254907 & 283524 & 271512 & 297878 & 361066 \\
\hline August & 155000 & 195549 & 243154 & 258377 & 254079 & 309219 & 336763 \\
\hline September & 141900 & 189346 & 240947 & 258440 & 257363 & 305629 & 354762 \\
\hline October & 128399 & 189234 & 229904 & 247565 & 255021 & 266562 & 341651 \\
\hline November & 110506 & 173077 & 199861 & 221603 & 242781 & 307276 & 296876 \\
\hline December & 125525 & 175963 & 227251 & 253591 & 268072 & 299013 & 347370 \\
\hline Total & 1457565 & 2085084 & 2576 & 2826709 & 2949332 & 3278598 & 3766 \\
& & & 142 & & & & 638 \\
\hline
\end{tabular}

Source: Website of Central Bureau of Statistics of Bali Province (Downloaded April 23, 2016).

\section{Four of Management Pattern of Bali Coastal Destination}

The development of tourism in Bali's beaches comes with several, utilized by tourism investor to build of hotel, bar and restaurant, and to develop beach tourism attractions, and so location of tourists expose to the sun known with term $3 \mathrm{~S}$ is Sea, Sand, Sun. There are four patterns in the management of sustainable coastal tourism, namely (1) Pattern of management by village tradition; (2) Pattern of management by village foundation; (3) Pattern of management by government authority/agency; and (4) Natural development (without pattern of management). Each of management patterns will be explained as follow.

\section{Pattern of Management by Village Tradition}

Pattern or system of Kuta coastal tourism management was implemented in this time is Pattern of Management by Tradition Village. Initiative of this management pattern forming comes from prominent figure of tradition village. But all of management feel the management pattern applied in this time still be traditional, so that still need the input from society and tourist. If there is input will be closed for the development of coastal tourism area to become better. 
Management Pattern by Tradition Village own the structure of organization and command system, namely under the Head of Tradition (Bendesa Adat) there is Coastal Management Unit Chief consorted by Vice Chairman, assisted by Treasurer and Administration. Chief of Coastal Management Unit be under division of infrastructure and cleanliness, and coordinator of field I, coordinator of field II, and coordinator of field III, where about each this coordinator own the member. Duty of each unit head or division, those are:

1) Chief of Coastal Management Unit, its duty to monitor, to coordinate of organization internal, merchant, tourist, and company or relevant third party that related with the cooperation and responsibility to all of coastal area management activity to cheep of tradition village.

2) Unit Vice Chairman, its duty assists the job of coastal management unit.

3) Treasurer, its duty handle the transaction from coastal merchant, together with fee, rent money in work agreement of cooperation, to make the financial report and all of activity related to payment system. Job system still in manually and traditional, and employees status is permanent, with the employees just one people and frequency work during eight clock per day.

4) Division of Administration, its duty to arrange the related/relevant bookkeeping with the coastal merchant, partys invited by cooperate concerning various contracts. Its Job system is manual still in computer work sheet not yet used the data base.

5) Division of infrastructure, its duty related with the equipments and office inventories and also prepares various infrastructures supporting, like cleanliness truck, etc. Its job mechanism is monitoring of infrastructure condition if there are damage, undertaking to repair or bring to service workshop. Employee status is permanent only one people and work is eight clocks per day.

6) Division of Cleanliness, its duty related with cleanliness of coastal tourism area. This division to conduct around control every day and also to involve the merchant to work together to keep cleanliness of coastal area. Its job system is to keep

http://ojs.unud.ac.id/index.php/eot cleanliness and conducting control the cleanliness every day. Employee's status is permanent as much three people oldly work every day that is eight clocks. Outside of cleanliness of task unity, there is also Coca Cola Beach Cleaning where take worker from tradition citizen that coordinated by the Company of Coca Cola and its remuneration also from party of Coca Cola.

7) Division of Field Coordinator there are three of team, with the member amount of every team as much eight people, so that totalize the employees as much 24 people. Undertake to monitor coastal situation related with security, cleanness, merchant, tourist freshmen, even which underway and also all aspect of related to various activity in coastal. Its job system is teamwork (on/off three shifts) with the employee's status is permanent and long work every day is 12 clocks.

Salary system was applied at all employees is monthly and salary obtained differ as according to position and duty of each worker. Operating expenses of coastal tourism Management in this region from:

1) Hotel fee per month, whereabouts there are fee difference according to hotel class. Revenue from hotel fee managed by Institute of Kuta Society Empowering Institute.

2) All merchant in coastal periphery, fee charge is varying depended on type of effort and citizen status who trading. General classification: merchant wear the umbrella is Rp 250.000,- per month, food merchant Rp 100.000,-per month, small scale food merchant equal to Rp 75.000,per month, others merchant equal to Rp 50.000 ,- per month, and merchant of tradition village citizen equal to $\mathrm{Rp}$ 15.000 ,- per month.

3) Visitors, mainly visitor using motor bike and motor car imposed by a retribution park.

4) Usually if there is even using of park land, so there is contribution to coast, its big depended by even that goes on.

Revenue per month for the management of coastal in this region $\pm \mathrm{Rp} 70$ million, which come from retribution of merchant \pm Rp 45 million, cooperation with 
the third party (contracts) $\mathrm{Rp} \pm 15$ million, and even which do not fasten $\pm \mathrm{Rp} 10$ million. While operating expenses equal to $R p \pm 50$ million, and the rest $\mathrm{Rp} \pm 20$ million pure into the cash of coastal management noted and reported by management each month. If tradition village there is program like development, Hindu ritual, etc, the fund can be subsidized to various the programs.

Constraints met in operational of coastal tourism management pattern in Kuta region that is, arranging of merchant and garbage. Solution which has been taken by that is sit together with related stakeholder in take action best to minimize of problem. Pursuant to confession, management party not yet satisfied to management pattern applied in this time, and hope there is input from tourist and society. Seems the management copes to arrange the coastal location become better, balmier for visitor by building restoration, renewal of tool and infrastructure with supporting by Badung Regency Government.

Kindliness which felt by manager by applying management pattern by tradition village that is, opening of opportunity business for society citizen, society economy expands, and region development is increase. But insuffiency felt that is, a lot of merchant so that location is too crawdad, view for tourist on the wane, just for coastal panorama because coastal area have solid of merchant Since expanding of Kuta coastal tourism, clear visible make-up of local and comer society prosperity, because society able to get the benefit from tourism through creation of various business activity which related with the tourism service, so that able to catch the tourist expenditure transacting goods and tourism service in Kuta coastal. Thereby coastal tourism growth of Kuta, indirectly have alleviation of poverty in Kuta region Kuta, previous about year 1970-an only a poor fisherman village.

Management pattern by Kuta tradition village have been able to create the coastal atmosphere of peaceful Kuta, balmy, and clean, so that this will become the capital to attract the tourist visit by continuing, and in the end will be able to support local society livelihood sustainability. Side the coastal tourism organizer of Kuta, suggesting that is,

http://ojs.unud.ac.id/index.php/eot
(1) governmental role in coastal tourism development very needed in provide tools and infrastructure, as well as increase of human resources quality through various training and construction, (2) needed tourism promotion which intensively so that can increase and attract the tourist enthusiasm to pay a visit to the tourism destination.

\section{Pattern of Management by Village Foundation}

Pattern or coastal tourism management system (Sustainable Coastal Tourism) is applied in this time in Sanur coastal referred as a Pattern of Management by Village Foundation. Institution Forming come from initiative of elite figure of Sanur countryside in a discussion forum, then compromise to form the Development Foundation of Sanur Village, shortened by Foundation of Sanur Village, whereabout one of its activity unit is manage the coastal area of Sanur becoming sentra of tourism development in Denpasar Municipality.

Sanur area under authority of Denpasar Municipality region, owning advantage of coastal tourism, whereabouts its coastal sandy white and suit for sunning for tourist which like to sun, so that obtained tourism attraction of $3 \mathrm{~S}$ that is Sea, Sand, and Sun. In Sanur coastal in the morning can see the sunrise from east horizon of Bali Island. In Alongside of Sanur coastal have location a lot of stars and non-stars hotels, restaurants and cafeteria, merchant, artshop.

Sanur Village Foundation led by a chief, and under the foundation there is Sanur Coastal Management Unit that led by a unit chief, that be under divisions, each owning duty that is:

1. Division of Cleanliness, its duty to clean the coast routinely was scheduled everyday and entangles the merchant and entrepreneur exists in each area. Cleaning division do some employees which have status is permanent employees, who do full-time 1 and part-time. This division always coordinates with Municipality Denpasar Cleanness Agency in to cleaning of Sanur coastal environment.

2. Division of Security, undertaking to secure the Sanur village region inclusive of Sanur 
coastal security. Work mechanism is to coordinate with village security institution (call: Bankamdes) and Sector Policy. This division employ some permanent employees and contract employees, whereabouts every sub of tradition village under Sanur village amount differ, namely north coast as much four people assisted by village security institution with every shift six people.

3. Division of Park, undertaking to arrange the incoming and exit of car going to Sanur coastal area. Each of sub tradition village (called Banjar) to manage the park areal in each area, and do the permanent employees with the rolling work system every 12 clock, that its amount depended of wide of region arranged.

4. Division of Administration, its duty to inventories of all coastal merchant, tourism entrepreneur, sailboat group and note the revenue and expenditure. Working co-ordinate with the area head, employing of permanent employees amount two people, and long work seven clock every day

5. Division of Crossing, undertaking to observe and note everyone to cross from Sanur to the Nusa Panda and Nusa Lembongan Island. This division employ the employees as much \pm 9 people, which have status is permanent employees, with the working time from 06.00 up to 11.00 am of middle Indonesia time.

6. Division of Public Utilities (like Toilet), undertaking to look after the public utilities cleanness. This division employs two people who have status of permanent employees, and long work 12 hours per day.

Salary system of employees in each division is monthly salary system and percentage from revenue, and level of salary according with theirs duty and position. While revenue for the operational expenses for north area management pattern \pm Rp 26.000.000,per month, that come from, (1) incoming fee of tourism area, (2) park motor bike and motor car, ( 3) merchant retribution, (4) crossing retribution to Nusa Penida and Nusa Lembongan island, ( 5) public utilities retribution, and (6) sailing boat retribution. This revenue after minus by the operational expenses about 50 percent, the rest channeled to tradition village, and from traditional villager used to repair of praying utilities(called: Kahyangan Tiga).

Positive Impact felt by manager with applying management pattern by foundation is requirement of tradition village of fund, for development as well as for ritual ceremony can be fulfilled coming from rest of Sanur coastal management revenue. All management not yet felt of insuffiency from this pattern, with the argument that as long as held of good control, so insuffiency not exist and if there is relative minimum and can be overcome. This matter can be proved by management statement, whereabout they are felt toward theirs performance from applied of this pattern. But there are constraints met in operational of coastal tourism management pattern in this region that is, difficult arrange the visitor, difficult arrange the merchant, and difficult manage the garbage. But solutions which have been taken that are discussion among related divisions and agree on the solution which must be taken.

In effort improve performance of this pattern, important every division always coordinate with the other stakeholder tourism in each of manage area. Example, division of cleanness have to always coordinate with cleanse agency of Denpasar Municipality, merchant at coastal alongside, and visitors, to direct the visitors to throw at its place and role of law have agree in manage area.

A lot of society of Sanur countryside citizens of its livelihood in Sanur coastal tourism, as merchant of food and beverage, merchant of souvenirs, guide for tourism attraction, hotel and restaurant workers, etc. Thereby tourism of Sanur countryside has been able to improve the society earnings, and indirectly can alleviation of local society poverty.

Implemented of this pattern seems have shown the good performance, whereas the Sanur coastal to be clean, peaceful, balmy and also beautiful, so that this capital will be able to attract the tourists to visit to Sanur coastal sustainability and society livelihood come from tourism can be sustainable. 


\section{Pattern of Management by Authority Agency}

Pattern of management implemented by Bali Tourism Development Corporation (BTDC) and now call Indonesia Tourism Development Corporation (ITDC) constitute of representative of central government authority called Controller Command $($ Komando Pengendali $=$ Kodal $)$ initiative by BTDC with involve relevant institution like Police of Territorial Water and Air (called: Polairud), Coastal Police (Polisi Pantai=Polpa), Tourism Police (Polisi Pariwisata $=$ Polpar), Sector Police $($ Polisi Sektor $=$ Polsek), and certain time involve the Tradition Village Security called Pecalang (Bali term).

Management pattern of 'Controller Command' owning structure of organization, system coordination and good job mechanism. Implemented this pattern to get the construction from vertical institution, for example work units to get the construction from higher institution, like security unit get the construction from Bali Regional Police (Polda Bali). BTDC own the division that is, security/fire guard, cleanness and maintenance, watering police, coastal police, and tourism police.

Security Division ( fire guard) owning duties that is, taking care of Nusa Dua coastal security, taking care of common area by security, assisting to overcome fire in area, construction and controlling toward coastal merchant. Security under coordination of operation division and Directorate Operation, divided to become four guard shift that is, morning, day, evening, and night. Territorial security coordinate with Sector Police of South Kuta, Tourism Police, Coastal Police, Watering Police, hotel security under coordination of head of BTDC security representing lengthening of Bali regional police. Sum up the coastal security labor of Nusa Dua that is, Sector Police 50 people, Coastal Police 12 people, Watering and Air Police nine people, tourism security eight people, BTDC security unity 75 people, Hotel Security 314 people, and Coastal Police are 21 people.

http://ojs.unud.ac.id/index.php/eot
Division of cleanliness and maintenance of garden and coastal own the duty that is, keep cleaning area, looking after gardening in area and coastal, to separate and chosen the inorganic and organic garbage. Cleanness is responsibility of BTDC maintenance unit under operation division. Work to be outsourcing by cooperation of Nusa Jaya of BTDC as much 160 people, with two shifts that are 06 s.d. 10.00 am middle Indonesia time, and evening $13.00-16.00 \mathrm{pm}$ middle Indonesia time. Cleanness working coordinated by field maintenance unit (called UPL-Upem).

Division of Police of Territorial Water and Air representing lengthening of hand of Bali Regional Police, owning duty that is, taking care of security of water territorial of Nusa Dua, taking care of coastal area security of Nusa Two, and assist to save the tourism get accident in coastal. Routine coordination each month through meeting of BTDC security. Work system namely patrol routinely with the rubber boat, jetsky, and car, divided into four shift that is, morning, day, evening, and night. While worker amount as much 10 people. Operating expenses from this division come from BTDC.

Division of Coastal Police representing lengthening of Bali Regional Police own the duty that is, taking care of security in coastal area of Nusa Dua, routine patrol to alongside of Nusa Dua coastal, and conduct the coordination to BTDC and hotels security. System of work in the form of patrol routinely with the bicycle and take walk. Work of coordination through monthly meeting of BTDC security and communications use the HT integrated. Frequency work 07.00-18.00 pm middle Indonesia time, divided into two shifts, morning and evening with the personnel amount 21 people.

Division of Tourism Police also represents the lengthening of Bali Regional Police own the duty that is, taking care of security in Nusa Dua tourism area, and gives the information to tourists. Work system with patrol routinely and coordinate in the form of monthly security meeting. Frequency of work from 07.00 am to $18.00 \mathrm{pm}$, with the personnel amount as much 12 people. 
Implementation of management pattern by authority agency like BTDC and own the mechanism work better, affecting positive toward conservation, security, freshment, cleanness, and harmonious in Nusa Dua coastal area, that finally support achievement of sustainable Nusa Dua coastal tourism.

A lot of tourism stakeholder, like food and beverage merchant, souvenir merchant, entrepreneur of hotel and restaurant, hotel worker, owner of speed boat patch or sailboat, and coastal attraction guide to obtain the benefit from existence of Nusa dua coastal tourism. Tourists during in coastal tourist destination of Nusa Dua expense their money to various transactions of goods and tourism service, and this tourist expenditure is under arrest by various stakeholder tourism. This means coastal tourism sustainable very having an effect on local society livelihood sustainable. Hence, effort this coastal tourism maintenance and conservation is very requires to be conducted in order tourists to come sustainability, so that able to give the livelihood to the local society sustainability.

Although coastal tourism management of Nusa Dua is progress and modern, but there are still society group outside Nusa Dua area, especially in Bualu Village and Tanjung Benua Village, like narrow land farmer, breeder, and seaweed farmer still to be impecunious. Because their activity is not related at all with the tourism and do not own the skill to follow to work in tourism, so that cannot follow to catch the tourism cake. This matter requires getting the attention from BTDC.

Until nowadays BTDC not yet owned of special program addressed in the effort poverty alleviation in Bualu Village and Tanjung Benua Village. Role of BTDC in the poverty alleviation indirectly under program is obliged to from government to side the Corporate Government, CG (called: Badan Usaha Milik Negara, BUMN) that is recognized with the title Partnership Program and Environment Construct, PPEC (called: Program kemitraan dan Bina Lingkungan, $P K B L)$. PPEC Program represent the program is obliged to for all BUMN of exist in Indonesia. This program this represent to exist

http://ojs.unud.ac.id/index.php/eot from Corporate Social Responsibility (CSR) or responsibility of company especially corporate government toward society and environmental around place location of effort them. But, confessed by BTDC, before existence of obligation from governmental party to perform the CSR to society, BTDC have conducted activities as existing their caring to environment about (Susrami Dewi, 2009).

However BTDC also conduct the Partnership Program (PP), especially in economic aspect. This program have been conducted since year 1992, but newly in the year 1997 supported by released of Minister Regulation. For this time legal force of PP as one of program CSR of a Corporate Government arranged in Regulation of State's Minister of Corporate Government No.: Per05/MBU/2007 about Partnership Program of Corporate Government with Small Industry and Program to Construct the Environment. After existence of the legal force, natures of PP which initially have the character of the grant nowadays become the rolling fund with the guarantee.

Special in execution of PP, BTDC conduct cooperation with two other parties, namely side the Badung Government in this matter represented by Badung Regency Cooperation Agency and side of Head of Environmental whereabouts applicant reside. Involvement of three stakeholders, namely BTDC, Cooperation Agency, and Environmental Head usually term by BTDC with Three Partiet. Yet in this time BTDC not more involve Badung Regency in execution PP. This Matter is caused by arise complain from partner candidate concerning extra fee which burdened to them when to arrange the request letter.

At this time PP to be one of indicator used in determining image or success of one Government Corporation in national eye. The using of PP as one of success indicator of a BUMN, confessed to become the constraint for BTDC in channeling loan fund particularly at small industry. 


\section{Natural Development (Without Pattern of Management)}

Coastal tourist destination in Bali, which start develop as well as developing, beside its growth there is managed professionally with principal of modern management, but there is also some tourist destination which its growth naturally or without intervention the human hand or without management. Yet in this paper taken only one as example, namely Nusa Lembongan coastal tourist destination in Nusa Lembongan Island in Klungkung Regency, Bali Province Indonesia.

Nusa Lembongan tourist destination covers two island of exist in Archipelago of Nusa Penida that is Nusa Lembongan and Nusa Ceningan. Nusa Lembongan tourist destination is the part of Nusa Penida Area which is located in Klungkung Regency. Distance of Nusa Lembongan tourist destination from Denpasar Town more or less $70 \mathrm{~km}$, from Klungkung Town more or less 30 $\mathrm{km}$, and from its district town that is Nusa Penida more or less $14 \mathrm{~km}$. Nusa Lembongan only can be reached through sea, which generally boat come from Bali Island through Port of Padang Bay (Karangasem Regency), Kusamba (Klungkung Regency), Sanur and Benoa (Denpasar Municipality). Nusa Lembongan tourist destination is the single archipelago in Bali becoming destination for activity of day trip (daily tour) for cruiser with all the form (catamaran, speed boat, pinisi) and size start from between 10 and 20 people capacities until hundreds people who leave from Benoa Port. Activity of this day trip originally expands in Nusa Lembongan and introduces the Nusa Lembongan as a maritime destination in world.

Decade of 1990-an is new chapter of tourism growth in Nusa Lembongan which is early with the luxuriant cruiser attendance that is operate of Bali Hi Cruises precisely year 1989, transporting hundreds of tourist per day. Successively followed by Waka Louka Cruises operating year 1991, Island Explorer Cruises, Sail Sensation Cruises and still a lot of again. Tour program offered by company mention is similar, covering attraction in sea and also tour in countryside.
Some of maritime tourism activity developing in Nusa Lembongan Island namely watersport (diving, surf bike, snorkling, banana boat, parasailing, water slid, cannoeing, fly fishing, around the island tour, pontoon restaurant, glass bottom boat, semi [of] submarine tour, jetsky). For the activity in continent, tourist invited to enjoy the island tour which offered by all cruise business. Several things seen by tourist of during this island tour are seaweed cultivation, countryside atmosphere, underground cafe, old house (traditional) and visit the mangrove forest.

Tour activity conducted by cruiser leaving from Benoa Port, stimulus of tourists to recognize nearer about Nusa Lembongan. Then emerge the request from tourist to lodge over there which responded by investor to build accommodate facilities for tourist which have international standard. Expanding of accommodate facilities also pioneered by above mentioned cruiser company, among other things: Waka Nusa Resort builded year 1993 to accommodate the tourist brought by Waka Louka ship, Tide Hai Hut ( Bali Hai Ship) year 1998, Coconut Beach Resort (Island Explorer ship), and Nusa Lembongan Resort (Ship of Sail Sensation) year 1999. Can be imagined how growth of a coastal tourist destination without management or let to expand by self, have of course more amount generating negative impact from compared positive impact, toward the physical environment of tourist destination, and social and economic of local society.

Base on observation and dept interview with all tourism stakeholder in Nusa Lembongan Island, seem that tourism growth without management have generated the positive impact in economic, and negative impact toward physical environment, social and economic. Positive impact of growth of Nusa Lembongan coastal tourist destination without management toward economic that is many builded hotels or cottages and coastal tourism attraction around territorial water of Nusa Lembongan, so have created a lot of job opportunity filled by local resident. Even a lot of local resident finally own the double livelihood, beside in the morning as fisherman catch the fish, day as worker in hotels or as guide in coastal attraction. Other society 
member also a lot of create activity that related with tourism, like merchant of food and beverage, merchant of souvenirs and so on, so that can increase their earnings. So can said that rapid develop of coastal tourism in this time in Nusa Lembongan, have given the benefit to local society in the form of extension of opportunity work and increasing of earnings, so that indirectly able to lessen of poorness in Nusa Lembongan.

Negative Impact of develop of Nusa Lembongan coastal tourist destination without management toward physical environment among other things,

1) Minimum of settlement to infrastructure and utilities of attraction water marked by, (a) disorganized of boat berth in port, (b) difficult of all accommodation service entrepreneur in searching place for the sunbathing, relax, swimming, snorkling, ( c) coast which ought to become the fascination of Nusa Lembongan tourist destination in the reality do not give the satisfaction for tourist. This matter has been confessed by a lot of tourist which come back from visit to Nusa Lembongan tourist destination.

2) Land utilization which is not optimal, marked by, (a) disorganized of building in coastal periphery, (b) uncontrolled to dig confessed by society, so that here and there a lot of hole bothering of traffic, (c) there are building which impinge the coastal border, building own the local society as well as building own outside investor.

3) Lack of handling to coastal cleanness, marked by some indicator that is, ( a) coastal cleanness in general less get the attention, especially from garbage of seaweed when fall off season of its leaf and also household garbage, (b) inexistence of controlling and reporting toward tourism actors throwing away its waste to coast.

4) Inexistence of special controlling toward coral reef and other coastal component becoming of island asset, marked by some indicator that is, (a) controlling inexistence to catch sea biology, like coral reef, decorate fish) and coastal sand, (b) controlling inexistence to fish bomber in coastal territorial water, (c) controlling inexistence to exploiting of coral reef, especially for diving activity by tourist, and (d) less organize of activity which have coronet of environment conservation, like of greening activity of hairless mangrove forest, cultivation of coral reef that damage, and counseling to related with the effort of natural conservation.

5) Density of water traffic is not controlled, marked by special arrangement inexistence to ship traffic and tourism attraction.

\section{Negative impact to social in the form, i.e.:}

1) Coastal consumer security is not guaranteed, marked by some indicator that is, (a) special agency inexistence to monitor of coastal situation as a whole especially to coastal consumer safety namely tourist, (b) guide inexistence in territorial water of referring to coastal use.

2) Lack of information related with coastal existence as a tourist destination.

3) Resident arrogance, marked by indicator that is, ( a) sense of belonging of destination abundant cause the resident do at will, ( b) local resident at will to utilize the exist land, although that land have been contracted by external investor, (c) do not mind the beautiful and harmoniously of environmental, (d) park their car promiscuously in hotel areal, without caring that matter can disturb the view, (e) park the boat promiscuously without caring that guest also wish to swim in coastal.

Negative impact toward economics of all hotel entrepreneur in the form of imposition of tariff of helper service uncontrollably, marked by special controlling inexistence to all helper behavioral, and tariff imposed to users at will helper and often have extortion nuance. Accumulate from negative impact to physical environment, social and economic, sooner or later will become the boomerang for Nusa Lembongan tourist destination. Probably slowly Nusa Lembongan coastal tourist destination will be left by tourist, and in the end the tourist destination mention will die or destroy. This has been become of a tourist destination in Asia-Pacific; dead cused there is not tourist to visit there. Finally will valid an expression "Tourism Destroy Tourism", or "Tourism Kill Tourism". However need also 
underlined that this expression do not only valid for tourist destination without management, but also valid for the tourist destination with a management, if its management less nicely.

However before death of Nusa Lembongan coastal tourist destination (hopefully is not happened), Government of Province or Regency Government need intervention with soon establish the authority agency, special to manage the Nusa Lembongan coastal tourism. This agency conducts the resettlement by making Master of Coastal Plan Tourism Development of Nusa Lembongan. Through this way, Nusa Lembongan coastal tourism will sustainable.

\section{Concluding Remark}

Since develop of coastal tourism in Bali, arisen four approach or pattern in to manage of sustainable coastal tourism, namely pattern of management by village tradition (desa adat), pattern of management by village foundation, pattern of management by government authority agency, and natural development (without pattern of management).

Two management patterns management by village tradition and management by village foundation initiatives by local community and its developing, local community livelihood in all long of beach very depending on tourism. While, management by authority agency initiatives are mainly applied by the central government in Jakarta.

Coastal tourism managed through the three kinds of management approaches are generally good, particularly on environmental security, tourists safety, maintaining clean environment which are made possible through mobilization of task forces. On the other hand, coastal areas without planned tourism management, generally suffers from several problems.

Hence the development of sustainable coastal tourism should be managed by one of institution which may be that of a local community or a governmental authority/agency.

\section{References}

Antara, M. and Pitana, G. (2009) 'Tourism Labour Market in the Asia Pacific Region: The Case of Indonesia', in Fifth UNWTO International Conference on Tourism Statistics: Tourism an Engine for Employment Creation. Bali.

Ariani, M. (2004) Analisis Kebutuhan Tenaga Kerja pada Hotel Berbintang di Kabupaten Badung. Universitas Udayana.

Radetzki-Stenner, M. (1989) Internationaler Tourismus und Entwicklungsländer: die Auswirkungen des EinfachTourismus auf eine ländliche Region der indonesischen Insel Bali. LitVerlag.

Susrami Dewi, N. (2009) Peran Bali Tourism Development Corporation (BTDC) dalam Pengentasan Kemiskinan di Desa Bualu dan Tanjung Benua Kawasan Pariwisata Nusa Dua. University of Udayana,.

Vorlauter (1996) Ourimus in Entwicklungslanders Entwicklung durch Fremdenverkehr. Darmstadt: Wissenschaftliche Buchgeselhschaft.

Yoeti, O. A. (1996) Pemasaran Pariwisata. PT. Angkasa Bandung. 